\title{
Data Logger Suhu Dan Tekanan Pada Smart Biogas Sampah Rumah Tangga Menggunakan MPX5500DP
}

\author{
Ratna Ika Putri ${ }^{1}$, Muhamad Rifa' ${ }^{2}$, Abella Novatna Anjarsari ${ }^{3}$ \\ Submission:11-02-2020, Accepted: 17-03-2020
}

\begin{abstract}
The process of processing household waste into biogas is carried out using fermentation technology. Fermentation technology is the process of decomposition of organic compounds to produce energy and changes in the substrate become new products by microbes. In addition, the fermentation technique that has been done by fermenting household waste produces methane gas content $\left(\mathrm{CH}_{4}\right)$. To process household waste into biogas is to use biodigester. Biogester is a closed space that is used for the waste fermentation process which is assisted by microbes. Using a biodigester is expected to accelerate the fermentation process of household waste into alternative biogas materials because of the airtight biodigester state. A temperature and pressure data logger tool is designed on smart biogas household waste using the MPX5500DP sensor. The MPX5500DP sensor will detect the amount of gas pressure from the biogas results because the range of readings from this sensor is in accordance with what is needed, while the DHT22 sensor uses a large temperature reading because the temperature in the biodigester is not too large between $28^{\circ} \mathrm{C}-4^{\circ} \mathrm{C}$. From the results of reading the temperature and pressure values, the data will be processed by the Arduino Uno Microcontroller and stored data by the data logger. Based on the test results, the temperature measurement error readings of $0.81 \%$, while for the pressure measurement of about $3.5 \%$.
\end{abstract}

Intisari- Proses pembuatan sampah rumah tangga jadi biogas menggunakan teknologi fermentasi. Fermentasi adalah adanya penguraian bahan organik untuk menjadi bahan energi serta adanya perubahan senyawa menjadi produk baru yang dibantu oleh bakteri. Selain itu,fermentasi yang sudah dilakukan dengan memfermentasi sampah rumah tangga menghasilkan kandungan gas metana $\left(\mathrm{CH}_{4}\right)$. Untuk mengolah sampah rumah tangga menjadi biogas adalah menggunakan biodigester. Biogester adalah tempat tertutup yang digunakan untuk proses fermentasi sampah yang dibantu dengan bakteri. Dengan biodigester dapat mempercepat proses fermentasi sampah rumah tangga menjadi bahan alternatif biogas karena keadaan biodigester yang kedap udara. Dirancang sebuah alat data logger suhu dan tekanan pada smart biogas sampah rumah tangga menggunakan sensor MPX5500DP. Sensor MPX5500DP yang akan mendeteksi besar tekanan gas dari hasil biogas tersebut karena range dari pembacaan dari sensor ini sesuai dengan yang dibutuhkan, sedangkan untuk pembacaan besar suhu suhu

\footnotetext{
${ }^{2}$ Ratna Ika Putri adalah Dosen Jurusan Teknik Elektro Politeknik Negeri Malang, email : ratna.ika@polinema.ac.id

${ }^{3}$ Muhammad Rifai adalah Dosen Jurusan Teknik Elektro Politeknik Negeri Malang email: muh.rifai@polinema.ac.id

${ }^{1}$ Abella Novatna Anjarsari adalah Mahasiswa Jurusan Teknik Elektro Politeknik Negeri Malang email: abellanovan@gmail.com
}

digunakan sensor DHT22 karena suhu di dalam biodigester rangenya tidak terlalu besar antara $28^{\circ} \mathrm{C}-40^{\circ} \mathrm{C}$. Dari hasil pembacaan nilai suhu dan tekanan, data tersebut akan diolah oleh Mikrokontroller Arduino Uno dan disimpan datanya oleh Ratna Ika Putri: Data Logger Suhu dan Tekanan... data logger. Berdasarkan hasil pengujian, kesalahan pembacaan pengukuran suhu sebesar $0.81 \%$, sedangkan untuk pengukuran tekanan sekitar $3.5 \%$.

\section{Kata Kunci_- Data Logger, Biogas, Tekanan, Sampah.}

\section{Pendahuluan}

Padatnya Pemukiman serta rendahnya kesadaran masyarakat membuang sampah meyebabkan timbulnya pencemaran lingkungan yang berakibat munculnya bau tidak sedap, banyak lalat dan sering terjadinya peledakan gas metana di udara. Salah satu cara untuk mengatasi pencemaran tersebut adalah memanfaatkan sampah rumah tangga menjadi bahan baku energi alternatif biogas. Sampah sayuran sesungguhnya merupakan limbah organik yang berpotensi untuk diolah menjadi biogas[1]

Untuk mengolah sampah rumah tangga menjadi biogas adalah dengan menggunakan biodigester. Biogester adalah ruang tertutup yang digunakan untuk proses fermentasi sampah yang dibantu dengan mikroba[2]. Dengan menggunakan biodigester diharapkan dapat mempercepat proses fermentasi sampah rumah tangga menjadi bahan alternatif biogas karena keadaan biodigester yang kedap udara [3-5]. Beberapa parameter yang mempengaruhi kinerja pada sistem biogas yaitu suhu digester dan tekanan. Suhu dan tekanan pada biogas harus selalu terpantau untuk meningkatkan efisiensi dan efektifitas proses dan hasil dari biogas. Sistem pemantauan suhu dan tekanan melalui android untuk sistem biogas telah diteliti [6][7]. Pengukuran tekanan gas metan telah diteliti dengan mengaplikasikan mikrokontroler [4] dan juga menggunakan metode Anaerobic Baffled reactor (ABR)[8].

Untuk itu artikel ini membahas sebuah alat data logger suhu dan tekanan pada smart biogas sampah rumah tangga menggunakan sensor MPX5500DP. Data logger merupakan peralatan untuk mengumpulkan dan merekam data untuk memantau suatu kondisi [9]. Sensor MPX5500DP yang akan mendeteksi besar tekanan gas dari hasil biogas tersebut karena range dari pembacaan dari sensor ini sesuai dengan yang dibutuhkan, sedangkan untuk pembacaan besar suhu digunakan sensor DHT22 karena suhu di dalam biodigester rangenya tidak terlalu besar antara $28^{\circ} \mathrm{C}-40^{\circ} \mathrm{C}$. Sensor DHT 22 telah digunakan untuk mengendalikan suhu dan kelembaban udara dan menghasilkan kinerja yang baik[10]. Untuk dapat mengetahui besarnya nilai suhu dan tekanan udara pada smart biogas maka diperlukan data logger . Data logger pada alat ini dapat memantau perubahan suhu dan tekanan udara pada smart biogas , karena data logger dapat menyimpan data hasil perubahan suhu dan tekanan udara setiap waktu. 


\section{TinjauAn PustakA}

A. Sampah Rumah Tangga

Sampah rumah tangga yaitu sampah yang berbentuk padat yang berasal dari sisa kegiatan sehari-hari di rumah tangga, tidak termasuk tinja dan sampah spesifik dan dari proses alam yang berasal dari lingkungan rumah tangga. Sampah ini bersumber dari rumah atau dari komplek perumahan. Sampah rumah tangga terdiri atas sampah organik dan sampah anorganik. Sampah sayuran merupakan limbah organik yang dihasilkan setiap hari dalam jumlah besar. Limbah sampah sayuran yang sebagian besar berasal dari pasar tradisional seringkali terbuang begitu saja ataupun sebatas dijadikan pakan ternak[1].

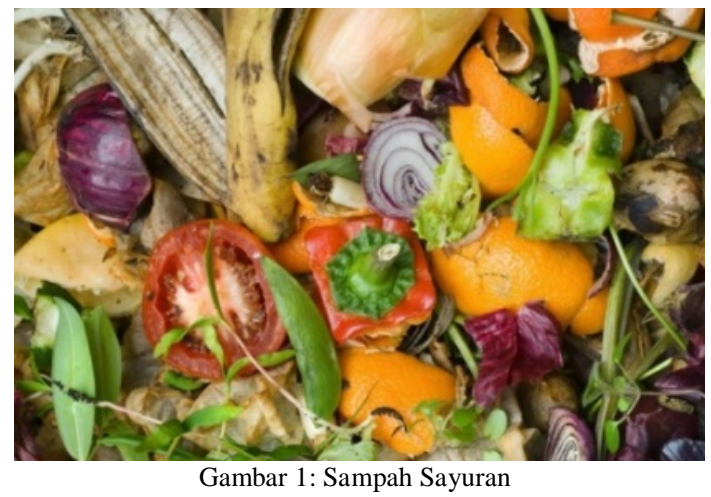

\section{B. Biodigester}

Biodigester adalah salah satu bagian penting dalam proses produksi biogas. Fungsi digester itu sendiri sebagai tempat penguraian kotoran sapi yang akan diendapkan. Adapun jenis digester yang dapat digunakan dalam proses produksi biogas diantaranya adalah:

1. Digester Jenis Fixed Dome

Digester ini juga sering disebut reaktor Cina, dinamakan demikian karena reaktor ini pertama kali dibuat di cina pada tahun 1930. Digester ini memiliki dua bagian yaitu digester sebagai tempat penguraian kotoran dan bagian penampung gas.

2. Digester Jenis floating dome

Digester floating dome atau sering disebut juga digester tipe india. Digester berjenis terapung ini pertama kali dikembangkan pada tahun 1937 di india. Digester ini memiliki bagian yang sama dengan digester tipe cina,perbedaannya terletak pada bagian penampung gas yang menggunakan peralatan bergerak berupa drum sebagai penampung gas metan.

3. Digester balon

Merupakan jenis digester yang banyak digunakan pada skala rumah tangga yang menggunakan bahan plastik sehingga lebih efisien dalam penanganan dan perubahan tempat biogas.Digester ini terdiri satu bagian yang berfungsi sebagai digester penguraian kotoran dan penampung gas sementara dalam satu ruang tanpa sekat[2].

Digester yang digunakan pada artikel ini tipe drum dengan berbemtuk kubus yang diberi nama Smart Biogas dengan daya tampung 1000 liter.

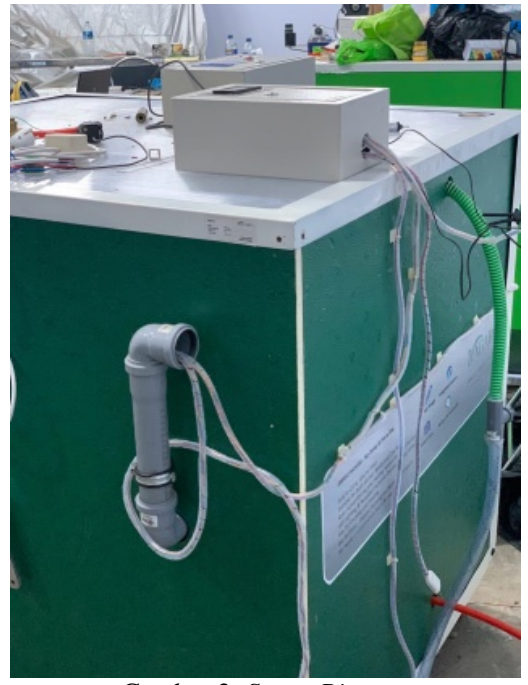

C. Mikrokontroler Arduino Uno

Arduino Uno adalah board berbasis mikrokontroler pada ATmega328. Board ini memiliki 14 digital input/output pin (dimana 6 pin dapat digunakan sebagai output PWM), 6 input analog, $16 \mathrm{MHz}$ osilator Kristal, koneksi USB, jack listrik, dan tombol reset. Pin-pin ini berisi semua yang diperlukan untuk mendukung mikrokontroler, hanya terhubung ke komputer dengan kabel USB atau sumber tegangan bisa didapat dari adaptor AC-DC atau baterai untuk menggunakannya[11].

Berikut adalah spesifikasi dari Arduino Uno:

Tabel I.

TABEL SPESIFIKASI ARDUINO [3]

\begin{tabular}{|c|c|}
\hline Mikrokontroler & ATMega328 \\
\hline Operasi Voltage & $5 \mathrm{~V}$ \\
\hline Input Voltage & $7-12 \mathrm{~V}$ (Rekomendasi) \\
\hline Input Voltage & $6-20 \mathrm{~V}$ (limits) \\
\hline I/O & 14 pin (6 pin untuk PWM) \\
\hline Arus & $50 \mathrm{~mA}$ \\
\hline Flash Memory & $32 \mathrm{~KB}$ \\
\hline Bootloader & SRAM $2 \mathrm{~KB}$ \\
\hline EEPROM & $1 \mathrm{~KB}$ \\
\hline Kecepatan & $16 \mathrm{~Hz}$ \\
\hline
\end{tabular}

\section{Data Logger Arduino Shield}

Data logger berbasis komputer ( atau yang disebut dengan istilah data acquisition) merupakan data logger yang telah terintregrasi dengan komputer, kinerjanya dapat meningkat seiring perkembangan teknologi prosesor komputer. Data dapat disimpan pada hard drive dan visualisasi dilakukan dengan memanfaatkan layar monitor komputer[9].

Data Logger Shield merupakan shield yang digunakan untuk melakukan penyimpanan data (data logging) pada SD Card, dimana shield ini kompatibel dengan Arduino Uno, Duemilanove, Diecimila, Leonardo, Mega R3/Mega ADK. Shield ini dilengkapi dengan RTC (Real Time Clock) yang digunakan untuk mengetahui waktu penyimpanan data[9].

Ratna Ika Putri: Data Logger Suhu dan Tekanan... 


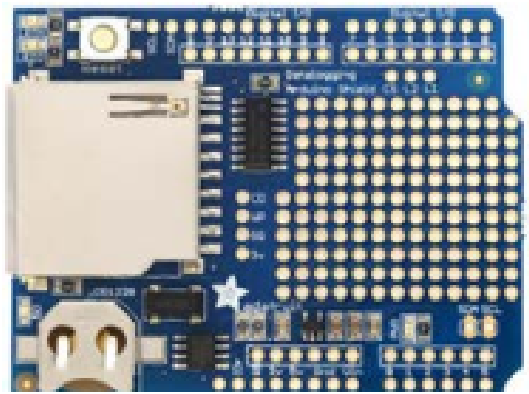

Gambar 3: Data Logger Arduino Shield [4]

\section{E. Sensor Suhu DHT22}

Sensor DHT22 terdiri dari 2 buah sensor didalamnya yaitu sensor kelembaban yang berupa capacitive-type humidity untuk pengukur kelembaban sensor ini bekerja berdasarkan perubahan kapasistas kapasitor apabila ada objek yang berada dalam daerah deteksinya yaitu adanya molekul air di udara dan sebuah temperature module untuk mengatur suhu yang terbuat dibuat dari campuran bahan semikonduktor yang dapat menghasilkan hambatan interistik yang akan berubah terhadap temperatur[10].

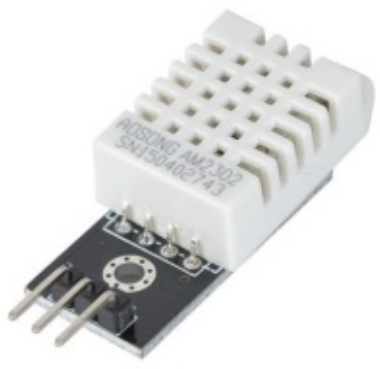

Gambar 4: Sensor DHT22[10].

\section{F. Sensor Tekanan MPX5500DP}

MPX5500D adalah sensor tekanan udara yang dapat mengukur tekanan antara 0 hingga $500 \mathrm{kPa}$ dan memiliki tegangan keluaran analog 0,2 hingga 4,7 V. Sensor ini memiliki toleransi akurasi maksimal 2,5\% pada suhu antara 0 hingga $125{ }^{\circ} \mathrm{C}$. Tipe sensor ini adalah differential yaitu mengukur perbedaan tekanan udara dari setiap sisinya[7].

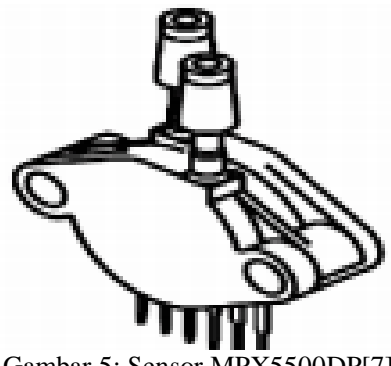

\section{Desain Data Logger Suhu Dan TEKanAN PADA BIOGAS}

Data logger suhu dan tekanan pada sistem biogas bertujuan untuk menyimpan data dan memonitor kondisi suhu dan tekanan pada digester sehingga proses sistem biogas dapat bekerja secara efektif dan aman. Hasil monitoring akan ditampilkan pada LCD. Gambar 6 menunjukkan diagram blok sistem secara keseluruhan. Sistem data logger ini terdiri dari sensor suhu untuk mendeteksi suhu, sensor tekanan untuk mendeteksi tekanan, mikrokontroller sebagai pengolah data, data logger berupa micro SD sebagai penyimpan data, LCD untuk menampilkan hasil pengukuran dan valve untuk mengeluarkan tekanan yang berlebih.

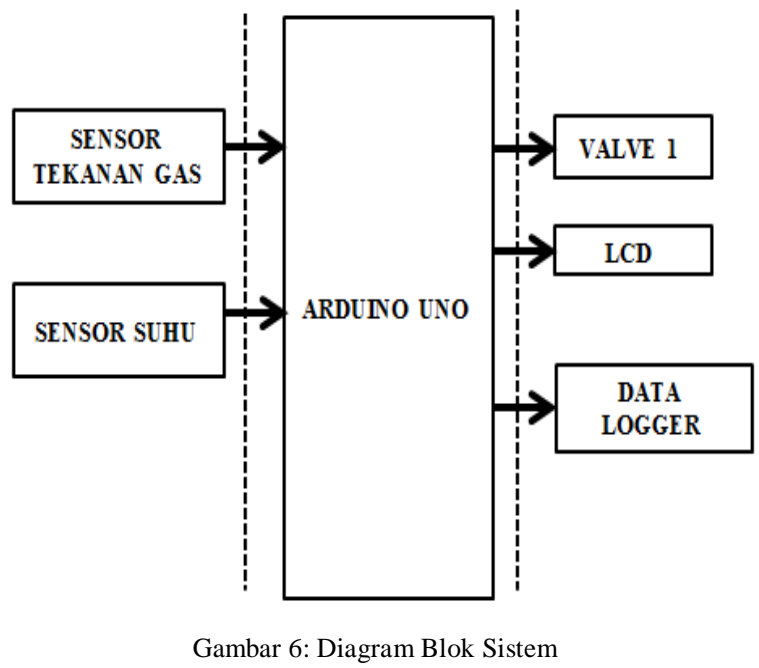

Prinsip kerja dari alat ini adalah proses fermentasi anaerob sampah rumah tangga yang akan menghasilkan gas metana. Dari blok diagram di atas alat ini menggunakan sensor gas MPX5500DP berfungsi untuk mengukur tekanan gas metana pada biogas dari fermentasi anaerob sampah rumah tangga. Ketika nilai tekanan gas metana mencapai nilai di atas yang ditentukan maka valve 1 akan terbuka sehingga gas metana akan mengalir ke tempat penyimpanan gas metana yang ada di luar digester. Ketika nilai gas pada digester sudah sudah dibawah setpoint makan valve 1 ikut tertutup. Hasil pembacaan sensor tekanan gas dan suhu akan disimpan pada data logger yang berfungsi untuk mencatat data dari waktu ke waktu baik yang terintegrasi dengan sensor dan instrumen di dalamnya maupun ekternal sensor. Selain itu data hasil pengukuran juga akan ditampilkan pada LCD. Gambar mekanik pada Smartbiogas seperti ditunjukkan pada Gambar 7. 


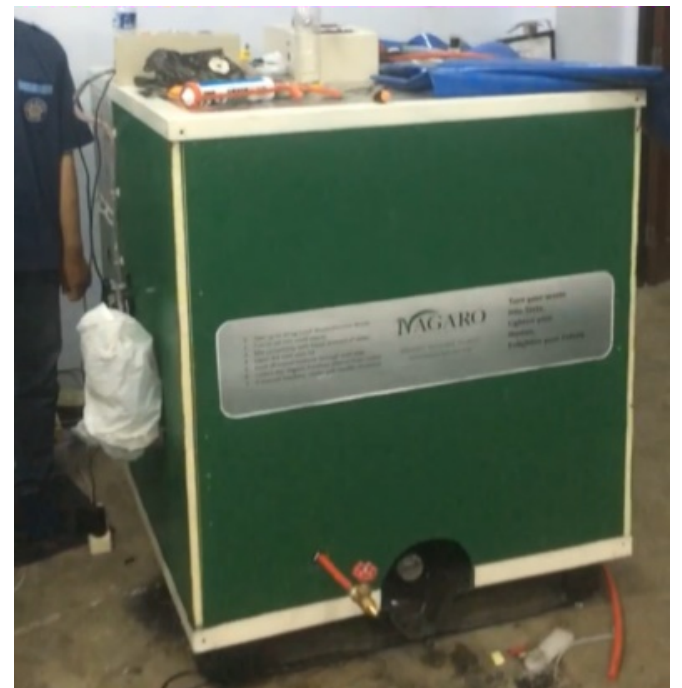

Gambar 7: Gambar Mekanik Tampak Depan

\section{A. Perancangan Rangkaian Data Logger}

Mikrokontroller Arduino Uno digunakan sebagai Master yaitu untuk pengolahan data, pembacaan sensor dan kontrol on off pada solenoid valve. Sedangkan untuk modul Data Logger untuk menyimpan data yang sudah diolah oleh Arduino Uno dengan periode waktu yang dibutuhkan oleh user. Rangkaian modul data logger terdapat SDA yang dihubungkan pada pin A4 dan SCL dihubungkan pada pin A5. SDA dan SCL merupakan bagian dari RTC. Untuk SCK (Serial Clock) dihubungkan pada pin D12, MISO (Master In Slave Out) dihubungkan pada pin D13, MOSI (Master Out Slave In) dihubungkan ke pin D11 dan untuk CS (Chip Select) dihubungkan pada pin D10. Gambar 8 menunjukkan rangkaian mikrokontroller. Sedangkan tabel II menunjukkan penggunaan pin mikrokontroller.

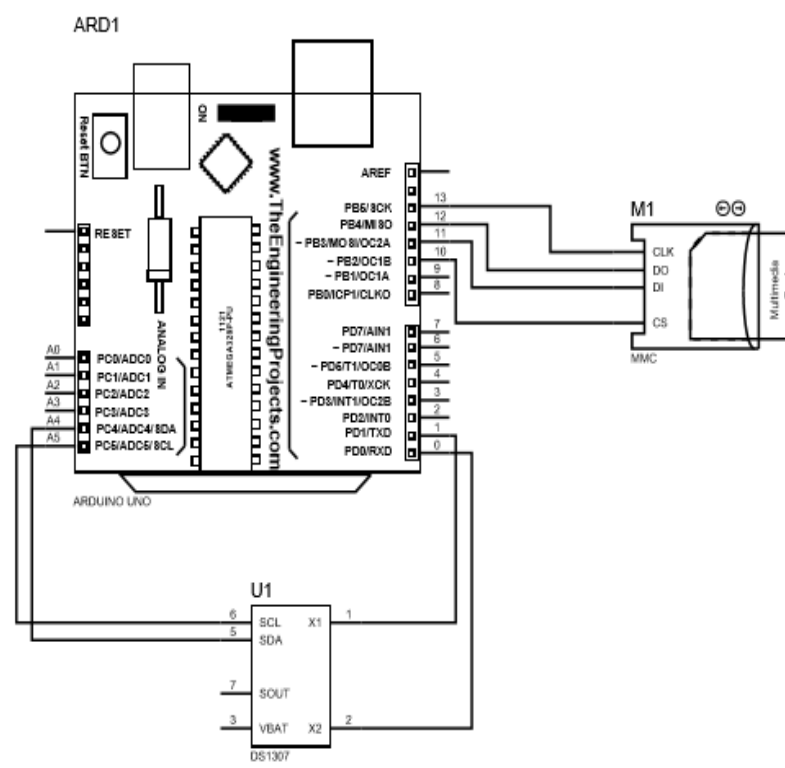

Gambar 8: Rangkaian Data Logger

Tabel II.

PENGGUNAAN PIN MIKROKONTROLER

\section{ARDUINO UNO DATA LOGGER SHIELD}

ISSN $1693-2951$

\begin{tabular}{|c|c|}
\hline $5 \mathrm{~V}+$ & $5 \mathrm{~V}+$ \\
\hline GND & GND \\
\hline A4 & SDA \\
\hline A5 & SCL \\
\hline D10 & CS \\
\hline D11 & MOSI \\
\hline D12 & SCK \\
\hline D13 & MISO \\
\hline A0 & DHT22 \\
\hline A2 & MPX5500DP \\
\hline
\end{tabular}

\section{B. Perancangan Rangkaian Sensor Suhu}

Rangkaian sensor suhu berfungsi untuk mendeteksi nilai suhu, seperti yang ditunjukkan pada Gambar 9. Seperti yang kita ketahui sesuai dengan datasheet bahwa sensor arduino uno menyediakan 10 bit pada setiap pin nya. Untuk sensor DHT22 berdasarkan datasheet menyediakan resolusi data 16 bit, dimana jika bit 15 bernilai " 1 " maka nilai yang dibaca negatif, sedangkan jika bernilai "0" maka nilai yang dibaca positif. Tabel III menunjukkan penggunaan pin DHT $22 \mathrm{ke}$ mikrokontroler.

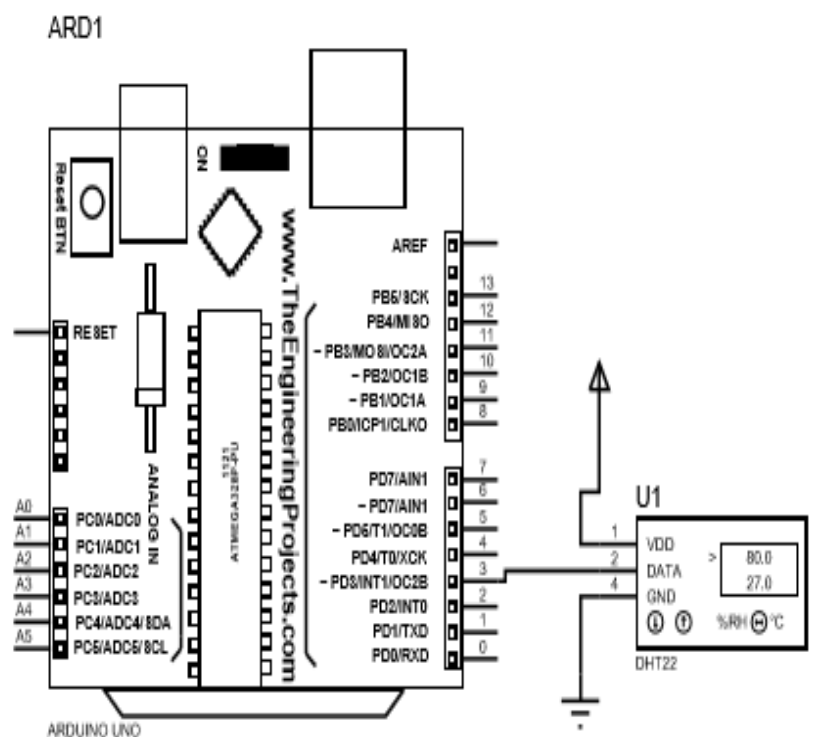

Gambar 9: Rangkaian Sensor Suhu

Tabel III.

PERANCANGAN RANGKAIAN SENSOR SUHU

\begin{tabular}{|c|c|}
\hline ARDUINO UNO & SENSOR DHT22 \\
\hline $5 \mathrm{~V}+$ & VS \\
\hline GND & GND \\
\hline A0 & DATA \\
\hline
\end{tabular}

C. Perancangan Rangkaian Sensor Tekanan

Rangkaian sensor tekanan berfungsi untuk mendeteksi nilai tekanan yang ada di dalam biodigester, seperti yang ditunjukkan pada Gambar 10.

Ratna Ika Putri: Data Logger Suhu dan Tekanan... 


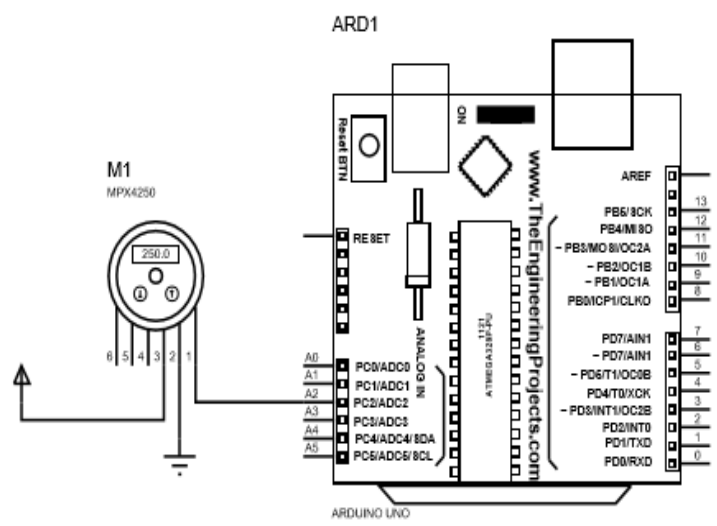

Gambar 10: Rangkaian Sensor Tekanan

Berdasarkan datasheet MPX5500DP, hubungan antara tegangan keluaran yang dihasilkan sensor dan tekanan yang diukur dapat dinyatakan dengan persamaan [10]

$$
\text { Vout }=\text { Vs }(0,0018 \mathrm{P}+0.04)
$$

Dimana Vs merupakan catu daya dan $\mathrm{P}$ merupakan tekanan. Tegangan keluaran sensor dihubungkan ke masukan mikrokontroler Arduino Uno. Arduino Uno memiliki 6 input analog, berlabel A0 sampai A5, yang masing-masing menyediakan resolusi 10 bit (yaitu 1024 nilai yang berbeda) maka hubungan antara keluaran ADC dengan tegangan keluaran sensor (Vout) dapat dinyatakan dengan persamaan

$$
A D C=\frac{\text { Vout } * 1023}{5 \mathrm{~V}}
$$

Tabel IV menunjukkan hubungan arduino uno dengan sensor MPX5500DP.

Tabel IV.

Perancangan RangKaian Sensor Tekanan

\begin{tabular}{|c|c|}
\hline ARDUINO UNO & SENSOR MPX5500DP \\
\hline $5 \mathrm{~V}+$ & VS \\
\hline GND & GND \\
\hline A2 & VOUT \\
\hline
\end{tabular}

\section{ANALISA DAN PEMBAHASAN}

\section{A. Pengukuran Suhu Biogas}

Pengukuran suhu biogas bertujuan untuk mengetahui suhu biogas sehingga dapat mengoptimalkan proses biogas. Pengukuran suhu menggunakan sensor DHT22 dan dilakukan pengujian peralatan dengan membandingkan hasil pengukuran sensor tersebut dengan thermometer. Termometer pembanding menggunakan thermometer digital merk Xiaomi. Data hasil pengujian sensor suhu seperti yang ditunjukkan pada Gambar 11. Berdasarkan hasil pengujian terdapat selisih atau error pengukuran antara data logger suhu dan thermometer pembanding. Berdasarkan hasil pengujian tersebut didapatkan Error rata-rata sebesar 0.83\%. Hal ini disebabkan karena faktor sensitivitas pembacaan dari sensor DHT22 berbeda dengan pembacaan termometer digital merk Xiaomi, atau karena peletakan sensor yang dekat dengan reaktor. Perubahan suhu terbaca setiap \pm 1 menit sekali pada Ratna Ika Putri: Data Logger Suhu dan Tekanan... sensor. Selisih suhu yang terbaca pada sensor DHT22 dengan termometer kurang dari $1 \square \mathrm{C}$.

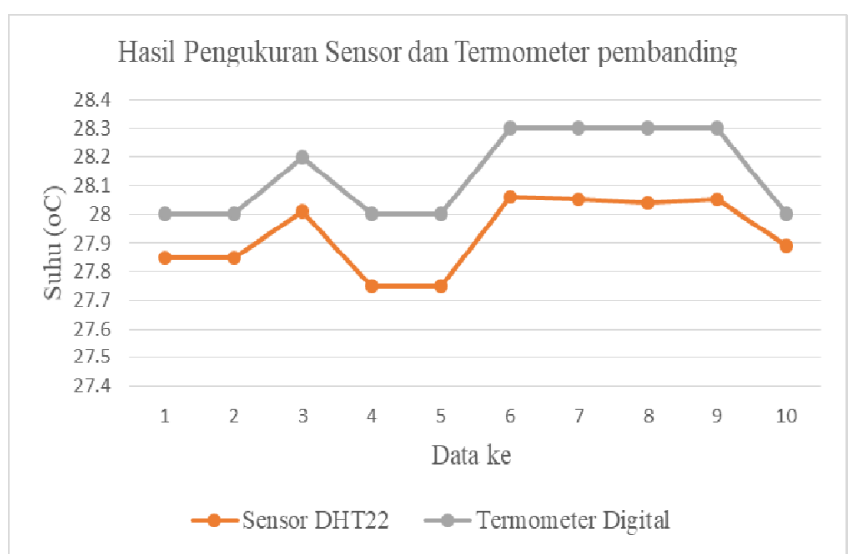

Gambar 11. Hasil Penggujian Sensor Suhu

Dari hasil pengujian sensor DHT22 yang disandingkan dengan termometer digital didapatkan error dengan rata-rata $0,81 \%$.

\section{B. Pengukuran Tekanan}

Pengukuran tekanan bertujuan untuk memonitor tekanan digester sehingga proses dapat terpantau dengan aman. Sensor tekanan menggunakan MPX5500DP yang memiliki jangkauan pengukuran hingga mencapai $500 \mathrm{kPa}$. Untuk mengkalibrasi hasil pengukuran dengan membandingkan hasil pengukuran alat dengan manometer analog. Kalibrasi dan pengujian alat ukur tekanan dengan menggunakan alat bantu kompresor. Hasil pengujian sensor tekanan seperti yang ditunjukkan pada Gambar 12.

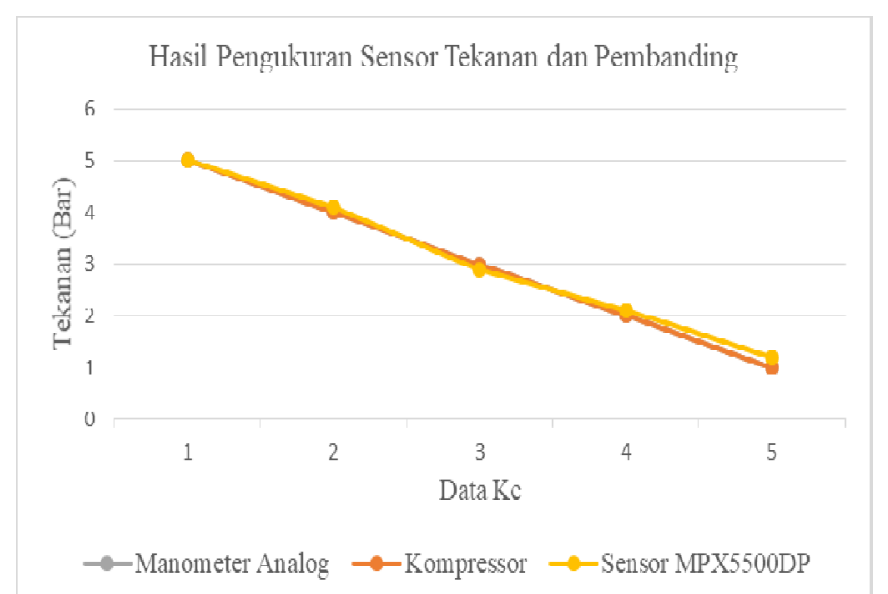

Gambar 12. Hasil Pengujian Sensor Tekanan MPX5500DP

Berdasarkan hasil pengujian, terdapat selisih angka pengukuran antara sensor MPX5500DP dan manometer analog. Hal ini dikarenakan ada beberapa faktor antara lain yaitu karena sensitivitas dari sensor MPX5500DP yang berbeda dengan manometer analog dan kesalahan pengamatan karena human error. Namun selisih angka antara keduanya

p-ISSN:1693 - 2951; e-ISSN: 2503-2372 
tidak terpaut jauh. Pada saat tekanan pada kompresor perlahan dikurangi pembacaan pada manometer ikut berkurang dan pada sensor juga ikut berkurang.

\section{Monitoring Suhu \& Tekanan Pada Sistem Biogas}

Untuk mengetahui kinerja data logger dan monitoring suhu dan tekanan pada biogas dilakukan pengujian sistem secara keseluruhan. Pengujian sistem alat secara keseluruhan keseluruhan dilakukan pengujian sebanyak 3 kali pada digester biogas dengan bantuan alat kompressor. Hasil pengujian sistem secara keseluruhan seperti yang ditunjukkan pada Tabel V.

Tabel V.

Hasil PENGUJIAN Sistem

\begin{tabular}{|c|c|c|c|}
\hline JAM & TANGGAL & SUHU & PRESSURE \\
\hline $10: 06$ & $03 / 06 / 2019$ & 28.09 & $0.00 \mathrm{bar}$ \\
\hline $13: 10$ & $12 / 06 / 2019$ & $29.22 \square$ & $2.89 \mathrm{bar}$ \\
\hline $08: 21$ & $17 / 06 / 2019$ & $29.15 \square$ & $2,84 \mathrm{bar}$ \\
\hline $10: 35$ & $23 / 06 / 2019$ & $28.03 \square$ & $2,73 \mathrm{bar}$ \\
\hline $19: 24$ & $05 / 07 / 2019$ & $27.10 \square$ & $2.72 \mathrm{bar}$ \\
\hline
\end{tabular}

Hasil dari data logging besar nilai suhu di dalam digester dan besar tekanan yang dibantu dengan alat kompressor dengan input tekanan yang awalnya 0 bar, kemudian tekanan ditambah sampai mendekati 3 bar. Pembacaan pada manometer analog dengan sensor mpx5500dp terdapat selisih sebesar 0,3-0,5 hal ini dikarenakan pembacaan human error. Sedangkan untuk sensor suhu sudah terkalibrasi dengan termometer xiaomi.

Pada hasil pemyimpanan di dalam SD CARD data pembacaan suhu dan besar tekanan tersimpan setiap 5 detik sekali. Terdapat pula data tangga, bulan, dan tahun serta jam yang juga tersimpan di dalam sd card. Tujuannya agar pengguna dapat mengakses data penyimpanan dengan mudah.

\section{KESIMPULAN}

Desain data logger suhu dan tekanan pada sistem biogas dengan menggunakan MPX5500DP telah dijelaska pada artikel ini. MPX5500DP memiliki jangkauan pengukuran tekanan hingga mencapai $500 \mathrm{kPa}$. Berdasarkan hasil pengukuran dan pengujian, data logger dapat mengukur dan meyimpan hasil pengukuran suhu dan tekanan pada sistem biogas. Kesalahan pembacaan pengukuran suhu sebesar
$0.81 \%$, sedangkan untuk pengukuran tekanan sekitar $3.5 \%$. Data logger dapat mempermudah pengguna untuk mengetahui atau memantau suhu dan tekanan gas yang ada di dalam digester dalam kurun waktu yang diinginkan. Sehingga proses fermentasi sampah rumah tangga menjadi biogas yang ada di dalam digester dapat terpantau dengan baik. Data logger berhasil menyimpan data sebanyak 720 data dalam waktu 1 jam dengan kapasitas 1020 byte per datanya. Peralatan ini akan dikembangkan untuk penelitian selanjutnya yaitu dengan menerapkan Internet of Thing (IoT) pada sistem data logger pada biogas sehingga dapat diakses melalui internet dan dipantau jarak jauh.

\section{REFERENSI}

[1] Andreas, Felix, Paramita SBU, Diyono Ikhsan, "Pembuatan Biogas Dari Sampah Sayuran”, Jurnal Teknologi Kimia dan Industri, Vol. 1, No. 1, pp 103-108, 2012.

[2] Qoriyatul, Fitriah, Dedi Irawan, M Prihadi Eko Wahyudi, "Pembangkit Listrik Tenaga Biogas dengan Digester Tipe Balon di Peternakan Sei Temiang Batam", Jurnal Integrasi, Vol. 10 No. 2, October 2018, 64-67, 2018

[3] Sunyoto, Danang, Saputro D, Suwahyo, "Pengolahan Sampah Organik Menggunakan Reaktor Biogas Di Kabupaten Kendal”, Jurnal Rekayasa Vol. 14 No. 1, Juli 2016.

[4] Ratna Ika Putri dan M Sarosa,Heli Tistiana,Sri Rulianah, "Pendeteksi Gas Metan Pada Sistem Biogas Berbasis Mikrokontroller”, Jurnal Eltek, Vol 12 No. 1, pp. 39-49, 2014.

[5] Meliala Pijar Ramanda, Amaliyah dan M Ramdlan Kirom, "Analisis Kinerja Digester Biogas Berdasarkan Parameter Oksigen”, eproceeding of engineering, Vol 02, No. 2, Agustus 2015.

[6] Alicya Putri, Nur Sultan Salahuddin, Marliza Ganefi Gumay. "Sistem Pemantau Suhu dan Tekanan Biogas Pada Biodigester Berbasiskan Android”, Konferensi Nasional Sistem Informasi 2018, 8-9 Maret 2018, Pangkal Pinang

[7] Sandi, S. Sudjadi, "Perancangan Sistem Akuisi Data Multisensor (Sensor Oksigen, Hidrogen, Suhu, Dan Tekanan) Melalui Website Berbasis Android", Transient: Jurnal Ilmiah Teknik Elektro. Volume 07,No. 2, pp. 457-463,September 2018

[8] Pratama, Aditya dan M Ramdlan Kirom , "Perancangan Alat Ukur Konsentrasi Gas Metana Dari Anaerobic Baffled Reactor (ABR) SemiKontinyu Dengan Substrat Susu Basi”, e-proceeding of engineering, Vol 04, No. 1, April 2017.

[9] Abdul , Azis Hasan dan Ian Kahfi Bachtiar,. "Perancangan Prototipe Datalogger Parameter Radiasi Matahari Dan Kecepatan Angin”, Skripsi, Universitas Maritim Raja Ali Haji, 2016

[10] Islam. Hanif Izzatul, "Sistem Kendali Suhu Dan Pemantauan Kelembapan Udara Ruangan Berbasis Arduino Uno Dengan Menggunakan Sensor DHT22 Dan Passive Infrared (PIR)", Prosiding Seminar Nasional Fisika Vol 05, Oktober 2016.

[11] Albert, P. Malvino. 1994,"Prinsip-Prinsip Dasar Elektronika”. Penerbit Erlangga. 